\title{
Inflammation and Vascular Injury as the Basis of COVID-19 Skin Changes: Preliminary Analysis of 23 Patients from the Literature [Letter]
}

This article was published in the following Dove Press journal: Clinical, Cosmetic and Investigational Dermatology

\author{
Alin Laurentiu Tatu $\mathbb{D}^{1,2}$ \\ Thomas Nadasdy (1D) \\ Florin Ciprian Bujoreanu $\mathbb{D}^{1,3}$ \\ I" St. Parascheva" Clinical Hospital of \\ Infectious Diseases, Dermatology \\ Department, Galati, Romania; ${ }^{2}$ Faculty of \\ Medicine and Pharmacy/Clinical \\ Department, Dermatology, Medical and \\ Pharmaceutical Research Unit/ \\ Competitive, Interdisciplinary Research \\ Integrated Platform, ReForm-UDJG, \\ "Dunărea de Jos" University, Galati, \\ Romania; 'Dermatology Department, \\ "Dunărea de Jos" University of Galati, \\ Doctoral School - Medicine, Galați, \\ Romania
}

\section{Dear editor}

We read with great interest and excitement the findings published in your journal by Yue Zheng and colleagues attempting to elucidate the pathological nature of SARS-CoV-2-related dermatologic manifestations. The authors speculate on interesting and relevant information related to the pathogenesis of skin manifestations and hypothesize that direct virally mediated destruction does not play a factor in the clinical manifestations seen in this emerging pathology. ${ }^{1}$ We believe that it is still too soon to rule out a direct viral pathogenesis for a portion of these skin lesions. Good evidence has emerged at this point in time to support the idea that the SARS-CoV-2 virus is capable of infecting human cells via the interaction between its Spike protein and the ACE2receptors on human cells. ${ }^{2}$ Outside of the heart, kidneys, lungs, and testes, ACE2-receptors are expressed by vascular endothelial cells in most organs, including those vessels found within the skin. ${ }^{3}$ It is true that as of yet no evidence exists of viral RNA within sampled skin lesions thought to be caused by SARS-CoV-2 infection, but evidence does exist that the virus is capable of infecting a variety of cells that express ACE2-receptors including the intestines and even those with a well-developed blood-tissue barrier, such as the testes. Limitations in RNA detection or sampling may limit our current ability to detect viral RNA in skin lesions, as evidenced by the initial negative results of studies done on viral RNA in semen samples that were later contradicted with further study. ${ }^{4}$ It is interesting to look at Zheng et al's analysis of skin manifestations that demonstrates such variation in onset, relation of severity, and pathological characteristics. It raises the possibility that some of these clinical lesions may have different pathophysiological backgrounds. We also did not see any uniformity in diagnostic methods for confirming SARS-CoV-2 in the patients of this paper, and that perhaps may lead to us seeing similar features of different etiologies manifested in these patients. As we discuss in our own paper, it is still difficult to differentiate between inflammatory skin manifestations related to medications versus those of viral etiology, as many of the apparent histopathological clues are non-specific, but recent reports of viral spike proteins in vascular endothelial cells and eccrine cells within the dermis does lend credence to the idea that the SARS-CoV-2 virus may play a direct role in the clinical
Correspondence: Thomas Nadasdy Spitalul Clinic de Boli Infecțioase Galați, Departamentul de Dermatologie, Strada Traian 393, Galați, 800179, Romania Tel +40 236334022

Email thomas.nadasdy@gmail.com 
manifestations we encounter. ${ }^{5}$ As such, some the vascular features showcased in Zheng et al's patient data may still be in part due to the direct cytotoxic effect of viral infection on endothelial cells within the skin and good statistical analyses as shown in Zheng et al's research may be key to helping categorize this emerging entity of SARS-CoV-2-related skin phenomena.

\section{Funding}

This article has no funding source.

\section{Disclosure}

The authors have no conflicts of interest to declare in this communication.

\section{References}

1. Zheng Y, Gong Z, Chen J, Lin Y, Liu Y. Inflammation and vascular injury as the basis of COVID-19 skin changes: preliminary analysis of 23 patients from the literature. Clin Cosmet Investig Dermatol. 2021;14:1-7. doi:10.2147/CCID.S278833

2. Lan J, Ge J, Yu J, et al. Structure of the SARS-CoV-2 spike receptor-binding domain bound to the ACE2 receptor. Nature. 2020;581:215-220. doi:10.1038/s41586-020-2180-5

3. Hamming I, Timens W, Bulthuis ML, Lely AT, Navis G, van Goor H. Tissue distribution of ACE2 protein, the functional receptor for SARS coronavirus. A first step in understanding SARS pathogenesis. $J$ Pathol. 2004;203(2):631-637. doi:10.1002/path.1570

4. Sharun K, Tiwari R, Dhama K. SARS-CoV-2 in semen: potential for sexual transmission in COVID-19. Int J Surg. 2020;84:156-158. doi:10.1016/j.ijsu.2020.11.011

5. Tatu AL, Nadasdy T, Bujoreanu FC. Familial clustering of COVID-19 skin manifestations. Dermatol Ther. 2020;33:e14181. doi:10.1111/ dth. 14181

\begin{abstract}
Dove Medical Press encourages responsible, free and frank academic debate. The content of the Clinical, Cosmetic and Investigational Dermatology 'letters to the editor' section does not necessarily represent the views of Dove Medical Press, its officers, agents, employees, related entities or the Clinical, Cosmetic and Investigational Dermatology editors. While all reasonable steps have been taken to confirm the content of each letter, Dove Medical Press accepts no liability in respect of the content of any letter, nor is it responsible for the content and accuracy of any letter to the editor.
\end{abstract}

Clinical, Cosmetic and Investigational Dermatology

Dovepress

\section{Publish your work in this journal}

Clinical, Cosmetic and Investigational Dermatology is an international, peer-reviewed, open access, online journal that focuses on the latest clinical and experimental research in all aspects of skin disease and cosmetic interventions. This journal is indexed on CAS.
The manuscript management system is completely online and includes a very quick and fair peer-review system, which is all easy to use. Visit http://www.dovepress.com/testimonials.php to read real quotes from published authors. 